\title{
A ROMAN LEGIONARY HELMET FOUND IN POLAND
}

BY

MARIA JAŽDŹEWSKA

THE excavations of the Late La Tène, Early Roman cemetery (1st century B.C./2nd-3rd centuries A.D.), carried out by the author at Siemiechów on the Warta river in July 1982 revealed a grave (designated by No. 25) whose inventory has caused a real sensation.

Most of the 39 cremation graves so far uncovered on site 2 at Siemiechów were richly furnished with weapons showing Celtic influences and with pottery indicating contacts between the Warta lands and the territories occupied by the Germanic Marcomanni. Bronze brooches are probably derived from the Roman province Noricum. A miniature representation of an iron shield is a unique find. The shield though of Celtic origin is dated by a fragmentary comb of rudimentary construction to the 2nd century A.D. Attention is also claimed by a set of miniature tools and various articles dated to the early 1 st century A.D.

In the context of these rich yet rypical urn and pit graves of the Late $\mathrm{La}$ Tène and Roman period the inventory of grave 25 represents a set of particularly valuable objects among which an iron helmet used as an urn is the most outstanding find.

The grave pit, discernible at a depth of $40 \mathrm{~cm}$. below the surface of the ground, formed a dark patch, $1.20 \times 1.60 \mathrm{~cm}$. in size, against yellow sand. As in other Late La Tène graves, the first layer of the pit contained vast amounts of broken pottery, including faceted rims, and a bow of an iron brooch of variety M (according to J. Kostrzewski's classification). At a depth of $46 \mathrm{~cm}$. below the surface of the ground lay an iron helmet filled with cremated human bones (Fig. 2), with an iron knife on top; another identical knife was found among the bones. The helmet and the remaining grave goods such as a ritually bent sword, a spearhead, a shield boss and an iron handle of a wooden bucket formed a compact concentration. On the ground of the brooch of $M$ variety and of pottery, found in the upper part of the pit, the set of objects has been dated to the very end of the Late La Tène period (1st century B.C./early 1st century A.D.).

The helmet found at Siemiechów is a Roman legionary helmet follow- 
ing Celto-Italian model (Fig. 3). Its hemispherical skull, $13.5 \mathrm{~cm}$. high, is relatively well preserved. It has a horizontal angular neckguard, now damaged, and two cheek-pieces, $12 \mathrm{~cm}$. long, attached by hinges. The inner side of the cheek-pieces has iron loops for a strap by which a leather lining was fastened to the inside of the helmet. The peak is fairly pronounced.

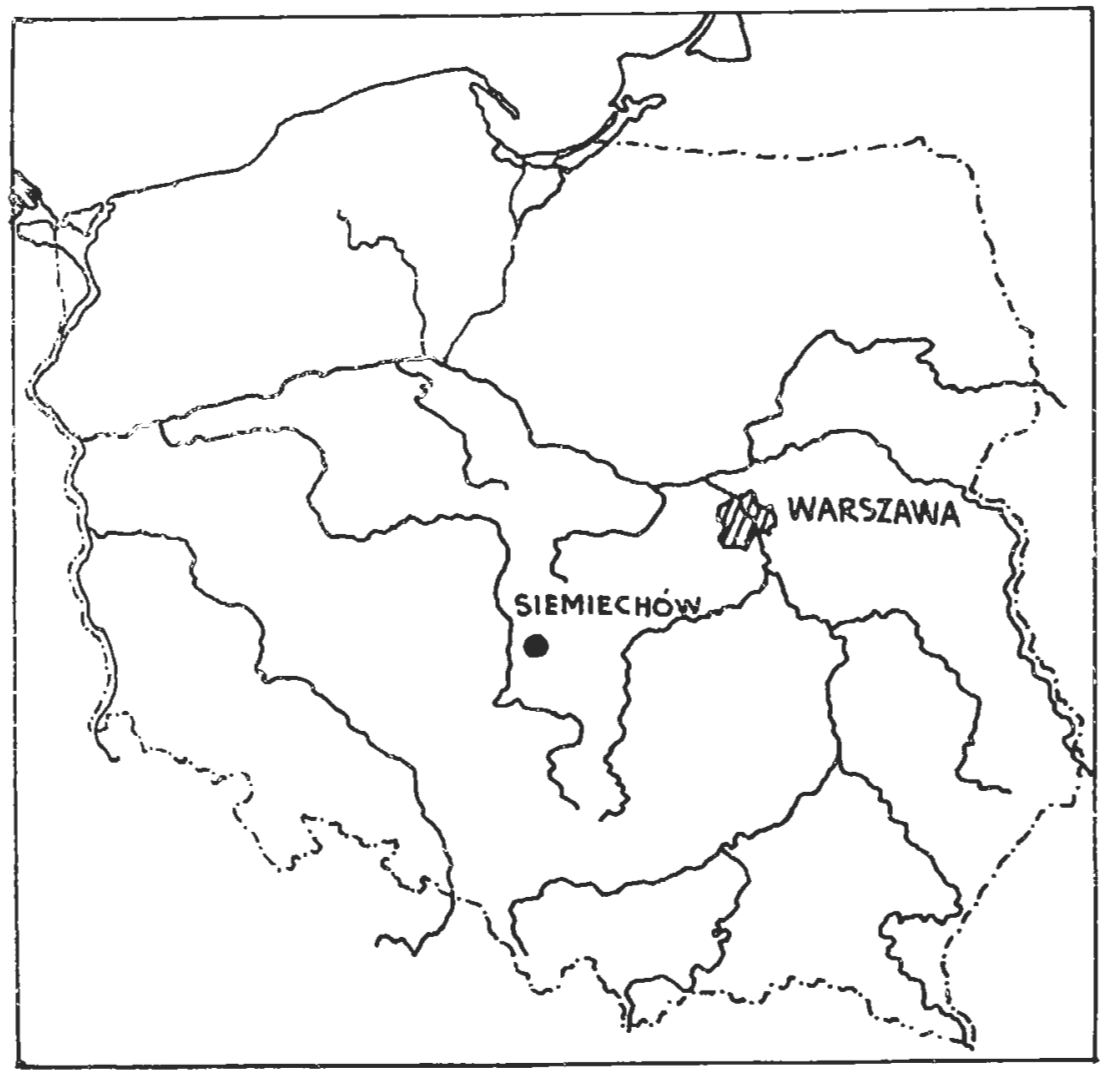

FIG. 1.-Location of the find.

The helmet has no analogies in Poland and therefore studies of finds from other countries had to be used, the following being the most useful: H. R. Robinson, The Armour of Imperial Rome (London 1975); O. Gamber, Waffe und Rüstung Eurasiens, Frübzeit und Antike (Braunschweig 
1978); H. Ubl, Die römiscbe Legion, in: Vindobona, Die Rümer im Wiener Raum, 52 (Sonderausstellung des Historischen Museums der Stadt Wien, 1978), as well as the studies by H. Klumbach and G. Webster. The helmet from Siemiechów, dated by the brooch of $M$ variety to the turn of the eras, has its closest analogy in the type of helmets defined

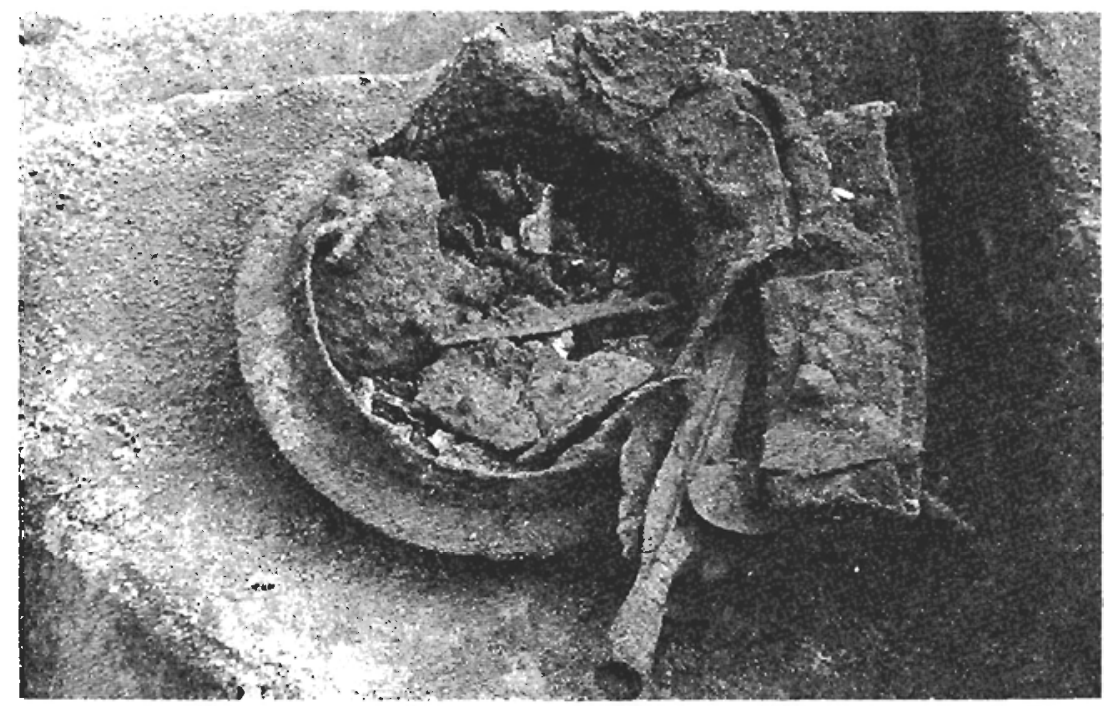

Fig. 2.-Grave No. 25 at Siemiechów. Helmet used as an urn.

by Robinson as Coolus $\mathrm{C}$, represented by a specimen from Liechtenstein dated to between late 1 st century B.C. to early 1 st century A.D. The iron cheek-pieces of this helmet «follow the original Gallic type attached to the Agen/Port iron helmets». ${ }^{1}$

A similar Roman legionary helmet from the close of the 1 st century B.C., published by H. J. Kellner, ${ }^{2}$ comes from Munich (Burlafingen) in western Bavaria (ancient Raetia). It is classified by Robinson as

1 H. R. Robinson, The Armour of Imperial Rome, London 1975, p. 31. G. Ulbert, professor of the University in Munich, on the ground of the photography of the helmet from Siemiechow - has reckoned it to the Agen/Port type. This type occurs in the 1st centuly B.C. - quite sure before the emperor Augustus. In professor G. Ulbert's opinion it is a gallic form, that was also used by the Roman imperial army.

2 H. J. Kellner, Die Römer in Bayern, München 1972, p. 25. 


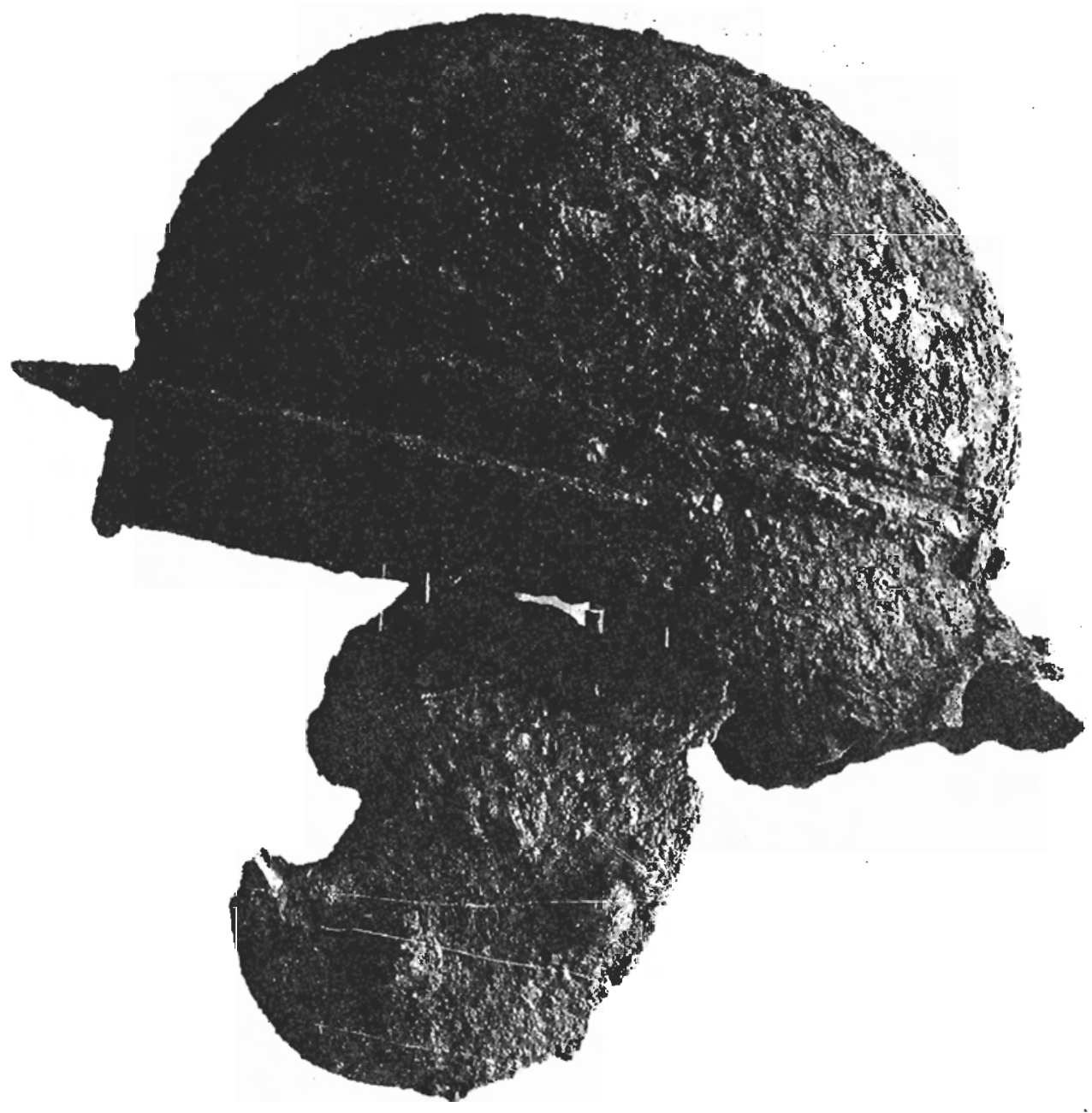

Fig. 3.-The Siemiechów helmet after the conservation. 
Coolus $G$ type, dated by him to the third quarter of the 1 st century A.D. ${ }^{3}$ More recent studies mention a helmet from Mihovo in north-western Yugoslavia, ${ }^{+}$dated to the Late La Tène period. This specimen, which is nearly identical with the Siemiechów helmet, is particularly valuable for comparative studies since it was found together with a long iron sword.

The Siemiechów helmet was accompanied by a similar iron sword, $1.01 \mathrm{~cm}$. long, in an iron scabbard. After its conservation it has a length of $97.3 \mathrm{~cm}$. 'The sword, thrice bent, is heavily damaged. Its blade at the tang is not curved but straight. It represents type III-IV according to the classification by M. D. and R. Wotagiewicz. This type, common at the end of the Late La Tène period, could have been modelled on long Celtic swords.

The spcarhead is better preserved. It is $\operatorname{sim}, 31.5 \mathrm{~cm}$. long, with a pronounced median rib, and ornaments etched on both sides of the blade. Spearheads of this kind, characteristic of the Late La Tène period, are associated with the Celts. Two knives with handles terminating in circles, are also modelled on Celtic specimens. The remaining grave goods include the above mentioned bucket handle and the shield boss with a very wide rim and rivets with flat disc-like heads. The shield boss represents Bohnsack's type V-VI" and agrees in chronology with the remaining objects.

The warrior buried in the grave under discussion was doubtlessly an important person. How did the helmet, once certainly worn by a Roman legionary, come to reach the region on the upper Warta will probably always remain a mystery. Various goods from the areas occupied first by the Celts and later by the Romans were imported to Central Europe at the turn of the eras. Trade contacts between the inhabitants of the present-day Slav lands and the Roman merchants are testified by ancient writers (Ptolemy, Pliny the Elder, Tacitus) as well as by archaeological finds recorded also in Poland where they had arrived by various routes.

B. Thomas's study of Pannonian helmets does not include analogical specimens. ${ }^{7}$ It seems thus feasible to assume that the helmet in question came not from the present-day Hungary but rather from the provinces of Ractia or Noricum (cf. the Minovo helmet), via Bohemia, the land of the Boii and via the land of the Marcomanni, and then by the land of the

II. R. Robinson, op. cit., p. 36.

il. J. Windl, Das La Tènc-und kaiserzeitliche Gräberfeld von Mibove, Unterkruin/Dolsjusko (Dissertation), Wien 1975, Bd. II, s. 189 ff.

'M. D. R. Wolagicwicz, Uzbrojenic lulności Pomorza Zachnodniego u progu maszej cry, in: «Materialy Zachodnio-Pomorskie» IX (1963-1964), p. 36.

"D. Bohnsack, Die Burgunden in Ostdeutschland und Polen wäbrend des letzten Jabrbunderts \%. Chr., Leipzig 1938, p. 59, fig. 36.

'B. Thomas, Hetme, Dolche, Schildc, Budapest 1971. 
Lugii (Lower Silesia). It is inacceptable to regard the buried warrior, wheter a Celt, a Teuton or a Slav, as a Roman soldier since only Roman citizens were allowed to serve in the Roman army. The trade, carried on by stages, seems thus the most likely way by which the helmet reached the Warta region.

In the opinion of J. Wielowiejski, ${ }^{8}$ Roman Swords (and other elements of arms and armour as well - addition mine) found their way into the northern countries either by trade or as a war booty, usually captured in the Danubian area. That arms were illegally sold by tradesmen to northern peoples is in Wielowiejski's view indicated by rules, issued by Roman authorities, forbidding such practices. According to him, most Roman imports, recorded in the trans-Danubian part of Austria, in Czechoslovakia and Poland, arrived via Noricum and Pannonia, mostly around the turn of the eras and in the first half of the 1st century A.D.

The helmet from Siemiechów is the earliest find of this kind in the area of Central European Barbaricum. According to K. Jaźdźewski the reign of Augustus, when the frontiers of the Roman Empire followed the courses of the Rhein and the Danube, offered the best opportunities for the helmet to have reached the territory of Poland.

${ }^{*}$ J. Wielowiejski, Kontakty Noricum $i$ Pannonii z ludami potmocnymi, Wrockaw 1970, pp. 47, 291, 294. 